\title{
Characterization of Dried Noodles From Local Durian (Durio zibethinus L.) Seed Flour
}

\author{
Ade Heri Mulyati, Diana Widiastuti, Qoriatun Najmulhasanah
}

\begin{abstract}
Durian seed flour contains nutritional chemical compound for consumption, especially carbohydrate and minerals that can be used as a substitution of wheat flour in various food products. Food diversification was conducted by utilizing natural resources through various steps such as processing durian seed flour as wheat flour replacement that fulfills the requirements of SNI (Standard Nasional Indonesia/ Indonesia National Standard) of wheat flour. The aim of this study was to utilize durian seed flour as a substitute for wheat flour in the manufacture of dry noodles. As a result, the durian seed flour can be used as an alternative raw material in various high nutritional food products and can help support food security. The results showed that durian seed flour contains $10.78 \%$ water, $4.45 \%$ ash, $8.97 \%$ protein, $0.52 \%$ fat, and $75.28 \%$ carbohydrate. Dry noodles made from durian seed flour based on organoleptic test results from panelists contained $2.46 \%$ water, $1.51 \%$ ash, $8.86 \%$ protein, $35.80 \%$ fat, and $51.37 \%$ carbohydrate. In Conclusion that the durian seed flour characteristics fulfill the SNI requirement of wheat flour and can be used as raw material for various food products such as dry noodles.
\end{abstract}

Index Terms: Dry Noodle, Durian Seed Flour, Substitution, Wheat Flour.

\section{INTRODUCTION}

The amount of wheat flour import is very high because of wheat flour producing by local producers is not enough to meet the wheat flour consumption needs in Indonesia. The carbohydrate content of durian seeds is very high that it can be processed into flour which has a high economic value and potential as the raw material of flour diversification products [1]. So far, the utilization of durian seeds is only limited as the raw material of chips with a relatively low market share, so it is expected that the durian seed waste processed into flour can produce various products and can increase the economic value of the durian seeds [2].

According to Prasetyaningrum (2010) people of Indonesia consume lots of durian fruit because it has a high nutritional value and delicious taste [3]. Durian skin and seeds are removed as waste, whereas the percentage is very high, the skin of $60-75 \%$ and the seed of $5-15 \%$ Compared to the weight percentage of the fruit flesh or the meat is quite low that is only $20-35 \%$, but the skin and the seeds have not been

Revised Manuscript Received on April 25, 2019.

Ade Heri Mulyati, Department of Chemistry, Faculty of Mathematics and Natural Science, Pakuan University, Indonesia.

Diana Widiastuti, Department of Chemistry, Faculty of Mathematics and Natural Science, Pakuan University, Indonesia.

Qoriatun Najmulhasanah, Department of Chemistry, Faculty of Mathematics and Natural Science, Pakuan University, Indonesia. fully utilized. The utilization of durian seeds can be done as efforts to reduce the waste generated and increase the economic value of durian seeds by processing durian seeds as alternative food products.

Durian seeds are the part of durians that are not consumed because it is slimy and can cause itching on the tongue. However, they contain very high nutrient compound such as protein, carbohydrates, fat, calcium and phosphorus. They can be used as an alternative food product after being processed into flour which can improve people's nutritional status and create a clean environment [4]. Durian seed flour can go through several physical, chemical and microbiological tests to ensure that the quality and feasibility substitution food products before they are consumed by a large of the community.

In Indonesia, the utilization of durian seeds was only limited to made durian seeds chips that have a low economic value, so it is expected that the durian seeds waste processed into flour can be made into products which are widely liked by people so it can increase the economic value of the durian seeds. One of the most popular food products in the community is noodle that has commonly been produced with wheat flour [5]. People consume noodles as a substitute food that is very practical, easy to process, and quickly served. The noodle industry is growing quite rapidly for every year. In the durian seed starch, there was amylose which affected gel formation and amylopectin which played a role in forming viscoelasticity, so that the dough formed will be more elastic and will expand.

Dry noodle is one of food product which is quite popular and favored by various level of society, especially among children. According to SNI 01-2974-1996, dry noodles are defined as dry food products made from wheat flour with the addition of other foodstuffs and permissible food additives, typically noodle-shaped. High carbohydrate content makes dry noodles can be used as an alternative source of carbohydrate substitute for rice. The aims of this study were to determine the characteristics of local durian seed flour by physically, chemically and microbiologically test as a substitute material for wheat flour in the processing food products of dry noodles. 


\section{MATERIALS AND METHODS}

\section{A. Material}

Durian seed materials can get from local durians from Jasinga, Bogor and durian seed waste from durian soup store in Bogor city.

\section{B. The Making and Characterization of Durian Seed Flour}

The durian sample was determined and then the durian seed waste was collected for sorting. The making durian seed flour was done through the process, as follows: by drying through soaking with $10 \% \mathrm{NaCl}$ solution for 30 minutes, washing and drying used oven at $50-60{ }^{\circ} \mathrm{C}$ or in the sun. Then durian seeds were milled and sifted with a mesh size 70 . The characterization was done physically (Color, and texture), chemically included water content (SNI 3751-2009), ash content (SNI 3751-2009), protein content (SNI 3751-2009), fat content (AOAC, 2000), carbohydrate content (AOAC, 2000), and microbiologically included Total Plate Count (SNI 3751-2009), molds (SNI 3751-2009), and Coliform and Escherichia coli contamination (SNI 3751-2009).

\section{The Making of Dry Noodles}

The dry noodles made from durian seeds flour with four formulations of composition durian seed waste: wheat flour, as follows: 0: 100 (S0), 25:75 (S1), 50:50 (S2), and 75:25 (S3). The resulting noodles were tested organoleptically, their nutritional contents by chemically and their food safety through microbiological tests. Repetition of the tests was done 3 or 4 times. Wheat flour and durian seed flour as the main raw material, with a predetermined treatment ratio, mixed with water that has been added with flavor enhancer and eggs, were stirred until all the ingredients were mixed. Furthermore, the mixture was pressed until the dough was mixed and chewy. The dough was diluted with the aid of the machine, cut into strands of noodles, and weighed approximately $100 \mathrm{~g}$ per serving. After a steaming process, the noodles were fried at a temperature of $140-150^{\circ} \mathrm{C}$ for 60 to 120 seconds [6].

\section{RESULT}

\section{a. Characteristics of Durian Seed Flour}

The Result Showed that Characteristics of durian seed flour can be seen in Table 1 .

Table 1. Characteristics of Durian Seed Flour

\begin{tabular}{|l|c|c|c|}
\hline \multicolumn{1}{|c|}{ Test } & Unit & Results & $\begin{array}{c}\text { SNI Wheat } \\
\mathbf{3 7 5 1 : 2 0 0 9}\end{array}$ \\
\hline Rendement & $\%$ & 38.46 & Rendement \\
\hline Color & - & Brownish white & Color \\
\hline Texture & - & Fine & Texture \\
\hline Flavour & - & Typical & Flavour \\
\hline Water & $\%$ & 10.78 & Max14.5 \\
\hline Ash & $\%$ & 4.45 & Max0.70 \\
\hline Protein & $\%$ & 8.97 & Min7.0 \\
\hline Fat & $\%$ & 0.52 & - \\
\hline Carbohydrate & $\%$ & 75.28 & - \\
\hline Total Plate Count & Colony/g & $4.2 \times 10^{3}$ & Max $1 \times 10^{6}$ \\
\hline Molds & COL/g & 10 & $1 \times 10^{4}$ \\
\hline
\end{tabular}

\begin{tabular}{|l|l|l|l|}
\hline Eschericia coli & Colony/g & $<3$ & 10 \\
\hline
\end{tabular}

The physical characteristics of color, flavor, and texture of durian seeds were analyzed by using human senses (organoleptic analysis) such as visual and sensory stimuli. Based on its color parameters, the light brown durian seed flour caused the brown epidermis of durian seeds. They are slimy and the epidermis could not be peeled. The browning process of durian seed flour will be got by drying it in the oven. The $38.46 \%$ soak of durian seeds were obtained from durian seeds that had been peeled.

The chemical characteristics of durian seed flour contained $10.78 \%$ water, $4.45 \%$ ash, $8.97 \%$ protein, $0.52 \%$ fat and $75.27 \%$ carbohydrate, fulfilled the requirements of Indonesia National Standards for Wheat Flour product No. 3751: 2009 had the maximum quantity contents of water of $14.5 \%$, as of $0.70 \%$, and minimum protein $7 \%$. Durian seed flour had very high carbohydrate content $(75.27 \%)$ and a very low-fat content $(0.52 \%)$, as a result, it was potential to be utilized as a raw material of various food products substituting wheat flour by utilizing the available natural resources. This result showed that durian seed flour could be widely used by society to support food security.

\section{b. Characteristic of Dry Noodles Made FromDurian Seed Flour}

Dry noodles made from durian seed flour based on Formula S0, S1, S2 and S3 were characterized organoleptically through rating test by 20 semitrained panelists with age ranges between 19-40 years. The results of the statistical analysis of the organoleptic test using variance analysis (ANOVA) with Duncan test with $95 \%$ confidence intervals for the rating test shown in Table 2.

Table 2. Statistics of Dry Noodle Rating Test

\begin{tabular}{|c|c|c|c|c|}
\hline \multirow{2}{*}{ Treatment } & \multicolumn{4}{|c|}{ Parameter } \\
\cline { 2 - 5 } & Color & Flavor & Texture & \\
\hline S0 & $6.15^{\mathrm{c}}$ & $5.35^{\mathrm{b}}$ & $5, .30^{\mathrm{bc}}$ & $5.60^{\mathrm{b}}$ \\
\hline S1 & $5.20^{\mathrm{b}}$ & $5.3^{\mathrm{a}}$ & $5.30^{\mathrm{ab}}$ & $5.40^{\mathrm{a}}$ \\
\hline S2 & $4.75^{\mathrm{b}}$ & $4.75^{\mathrm{a}}$ & $4.85^{\mathrm{bc}}$ & $5.05^{\mathrm{a}}$ \\
\hline S3 & $4.00^{\mathrm{c}}$ & $3.80^{\mathrm{b}}$ & $4.25^{\mathrm{c}}$ & $3.95^{\mathrm{b}}$ \\
\hline
\end{tabular}

Note: Different letters show different significance based on Duncan Test at $95 \%$ confidence intervals

Table 2 showed that the results of the fingerprint analysis for the rating test on the color, flavor, texture, the dry noodles produced had a significant effect at $95 \%$ confidence intervals based on the Duncan test. Dry noodles for S1 and S2 formulas were not significantly different, whereas S0 and S3 were significantly different. For flavor and taste, further Duncan Test showed that S0. S1 and S2 formulas were not significantly different, whereas S3was significantly different. The dry noodle textures of S0. S1, S2, and S3 formulas were significantly different. The color was influenced by the composition of durian flour with wheat flour in each formula, the higher the composition of the added durian seed flour, the color of dry noodle product was more brownish. The flavor and taste of dry noodles made from durian seed flour were influenced by the flavor and the 
distinctive taste from durian seeds. The texture of dry noodles product was strongly influenced by the process of the dry noodle production.

The chemical and microbiological tests were performed on dry noodles with S0 formula as the control and dry noodles selected by panelists with formula $\mathrm{S} 1$.

Table 3. Characteristics of Dry Noodles Made by Formula S0 and S1

\begin{tabular}{|c|c|c|c|c|}
\hline \multirow[b]{2}{*}{ Test } & \multirow[b]{2}{*}{ Unit } & \multicolumn{2}{|c|}{ Results } & \multirow{2}{*}{$\begin{array}{c}\text { SNI Dry Noodles } \\
\text { No. } \\
\text { 01-2976-1996 }\end{array}$} \\
\hline & & $\begin{array}{c}\text { Dry } \\
\text { Noodles S0 }\end{array}$ & $\begin{array}{c}\text { Dry } \\
\text { Noodles S1 }\end{array}$ & \\
\hline Water & $\%$ & 6.84 & 2.46 & Max 10 \\
\hline Ash & $\%$ & 3.35 & 1.51 & - \\
\hline Protein & $\%$ & 11.23 & 8.86 & Min. 8 \\
\hline Fat & $\%$ & 17.11 & 35.80 & - \\
\hline $\begin{array}{l}\text { Carbohyd } \\
\text { rate }\end{array}$ & $\%$ & 61.47 & 51.37 & - \\
\hline $\begin{array}{l}\text { Total } \\
\text { Plate } \\
\text { Count }\end{array}$ & $\mathrm{col} / \mathrm{g}$ & $<10$ & $3.6 \times 10^{2}$ & $\operatorname{Max} 1 \times 10^{6}$ \\
\hline $\begin{array}{l}\text { Escherichi } \\
\text { a coli }\end{array}$ & $\mathrm{col} / \mathrm{g}$ & $<3$ & $<3$ & $\operatorname{Max} 10$ \\
\hline Molds & $\mathrm{col} / \mathrm{g}$ & $<10$ & $<10$ & $\operatorname{Max} 1 \times 10^{4}$ \\
\hline
\end{tabular}

Table 3 showed that the chemical characteristics of dry noodles Formula S0 had a water content of $6.84 \%$ while dry noodles of durian seed flour and wheat flour (25:75) $2.46 \%$. The ash content of dry noodles of wheat flour was $3.35 \%$ and dry noodles of durian seed flour and wheat flour (25:75) was $1.51 \%$. The protein content of dry noodles of wheat flour was $11.23 \%$ and dry noodles of durian seed flour and wheat flour (25:75) was $8.86 \%$. The protein content of dry noodles Formula S0 fulfilled the first quality of Noodles, at least $11 \%$, while dry noodles with formula $\mathrm{S} 1$ fulfilled the second quality criterion of noodles, at least $8 \%$. The fat content of dry noodles of wheat flour was $17.11 \%$, while dry noodles of durian seed flour and wheat flour (25:75) was $35.80 \%$. The carbohydrate content was $61.47 \%$ for dry noodles of wheat flour (S1) and 51.37\% for dried noodles of durian seed flour and wheat flour 25:75 (S2) based on the carbohydrate content by difference analysis.

The microbiological characteristics (Table 3) showed that the results of Total Plate Count, Escherichia coli and mold tests fulfilled the requirements of SNI 3751: 2009 and were very safe for consumption by the community. The total plate counts obtained in both noodles samples were S0 formula $<10$ colony / g and S1 formula 3.6x102 colony / g. SNI Standards stated that the ALT value of dry noodles is $1 \times 106$ maximum. The dry noodles of S0 and $\mathrm{S} 1$ formulas contain Escherichia coli of $<3 \mathrm{col} / \mathrm{g}$, fulfilled the SNI requirement that was $10 \mathrm{COL} / \mathrm{g}$ max. Microbiological analysis of molds for S0 and S1 formulas, <10 colony / g, in accordance with SNI standard s that was $1 \times 104$ maximum.

The characteristics of durian seed flour fulfilled the standard criteria according to wheat flour SNI and in accordance with the previous research. The results study of Amin and Roslan, 2009 showed that durian seeds contained $6.5 \%$ water, $6.0 \%$ protein, $3.1 \%$ ash, $0.4 \%$ fat, $10,1 \%$ crude fiber and $73.9 \%$ carbohydrate. The protein content of durian flour was very high that was $8.97 \%$, exceeding the requirement of SNI wheat flour which was $7 \%$ maximum. The contents of chemical compounds in durian seeds as a result of Amid et al. 2012 study showed that durian seeds are an essential source of amino acid [7]. The most abundant amino acids from durian seeds were: leucine (30.9-37.3\%), lysine (6.04-8.36\%), aspartic acid (6.10-7.19\%), glycine (6 $(5.57-7.09 \%)$, valine $(4.5-5.50 \%)$, proline (3. 87-4.81\%), serine $(4.39-5.18 \%)$, threonine $(3.44-6.50 \%)$, isoleucine (3.30-4.07\%), and phenylalanine (3.11 -9.04\%).

The fat content of durian seed flour was very low that was $0.52 \%$ according to the previous study of $0.4 \%$. The dominant fatty acids of the lipid fraction of the durian seed were palmitic acid (C16: 0), palmitoleic acid (C16: 1), stearic acid (C18: 0), oleic acid (C18: 1), linoleic acid (C18: 2) and linolenic acid (C18: 2) (Amid et al., 2012). Carbohydrate content obtained was $75.27 \%$ higher than previous studies which only obtained $73.59 \%$ carbohydrate. The most abundant monosaccharides in the carbohydrate composition of durian seeds were galactose (48.6-59.9\%), glucose $(37.1-45.1 \%)$, arabinose $(0.58-3.41 \%)$, and xylose $(0.3-3.21 \%)$.

The food safety test based on microbiological analysis showed that durian seed flour full filled SNI 3751-2009 standard for the total plate number that was maximum of $1 \mathrm{x}$ 106 colony per gram, durian seed flour had a total plate number of $4,2 \times 103$. The maximum number of molds required was $1 \times 104$ colony per gram, therefore, with the yield of 10 colony/gram it full filled the standards of SNI 3751-2009. For E.coli bacteria, SNI stated that a maximum of $10 \mathrm{col} / \mathrm{gram}$, the results showed $<3 \mathrm{cols} / \mathrm{gram}$, so it full filled SNI. These results showed that durian seed flour produced had met the requirements of food safety based on microbiological aspects.

Durian seed flour was easily applied to a variety of preferred processed food products and it was easy to be fortified with other nutrients to increase nutritional values of the processed products such as those which had been done in dry noodle formulation with substitution of Kimpel flour (Xanthosoma sagittifolium) and addition of mung bean flour (Phaseolus radiatus L.) [8]. Because of flour was one form of semi-finished products that were easy applied, processed for various food products and easily fortified to increase the nutritional values of a food product.

\section{CONCLUSION}

Durian seed flour had characteristics that fulfilled SNI standards of wheat flour No. 01-3751-2009 that contained water, ash, protein, fat, carbohydrate, or $10.78 \%, 4.45 \%$, $8.97 \%, 0.52 \%$, and $75.28 \%$, respectively. Microbiological test resulted that Total plate count, E. coli, molds were $4.2 \mathrm{x}$ $103 \mathrm{col} / \mathrm{g},<3 \mathrm{Col} / \mathrm{g}$, and $10 \mathrm{col} / \mathrm{g}$. From the 4 formulas of durian seed flour substitution to wheat flour in the manufacture of dry noodles, it showed that the dry noodle product with a composition of $25 \%$ durian seed flour and $75 \%$ wheat flour was the acceptable formulation by panelist and full filled SNI standard of dry noodles No. 01-2976-1996 with nutrient contained water, ash, protein, fat, and carbohydrate respectively $2.46 \%, 1.51 \%, 8.86 \%$, $35.80 \%$, and $51.37 \%$ and microbiologically safe with Total Plate Count of 3.6x102 col / g, E. coli of $<3 \mathrm{Col} / \mathrm{g}$, and molds of $<10 \mathrm{col} / \mathrm{g}$. 


\section{ACKNOWLEDGMENT}

This research was conducted with the support of research fund of Ministry of Research and Technology based on research letter of budget year 2018 number 02 / LPPM-UP / KP - PSNI / II / 2018 between Research Institution and Community Service with lecturers / researchers of Pakuan University as derivative of Contract Research between Kopertis Region IV and Pakuan University Number 0801 / K4 / KM / 2018.

\section{REFERENCES}

1. A. M. Amin and A. Roslan Arshad. "Proximate composition and pasting properties of durian (Durio zibethinus) seed flour." International Journal of Postharvest Technology and Innovation, vol. 1, no .4, pp. 367-375, 2009.

2. A. Prasetyaningrum and M. Djaeni. "Feasibility of Durian Seeds as Alternative Food Material: Aspects of Nutrition and Techno Economics." Journal of Riptek, vol. 4, no. 11, p.37-45, 2010.

3. A. Prasetyaningrum, "Mechanization of Processed Durian Seeds into Competitive Food Products.” Journal of Riptek, vol. 4, no. 11, pp. 47-52, 2010.

4. R. W. Setio, R. Djalal and E. S Widyastuti. Effects of Addition of Durian Seed Starch (Durio zibethinus Murr) on the Physical Quality of Chicken Meatballs. Malang: Brawijaya University, 2013.

5. N. Dalimunthe. Influence of the Addition of Durian Seed Flour (Durio Zibethinus Murr) on the Taste of Wet Noodles. Medan: University of North Sumatra, 2011.

6. E. Z. Nasution. "The Making of Dry Noodles from Wheat Flour with Seaweed Flour Fortified with Soy Beans." Journal of Chemical Science vol. 9, no. 2, pp. 87-91, 2005.

7. B. T. Amid, H. Mirhosseini and S. Kostadinović. "Chemical composition and molecular structure of polysaccharide-protein biopolymer from Durio zibethinus seed: extraction and purification process." Chemistry Central Journal, vol. 6, no. 1, pp. 117-125, 2012.

8. I. A. Pratama and F. C Nisa. "Formulation of Dry Noodles with Substitution of Kimpul Flour (Xanthosoma sagittifolium) and Addition of Green Bean Flour (Phaseolus radiatus L)." Journal of Food and Agro-industry, vol. 2, no. 4, pp.101-112, 2014. 